SECTION 18. Culturology.

Svetlana Iliinichna Shamarova

Associate Professor, Ph. D. in Philology,

The Ufa state university of economy and service, Russia

shamarova@list.ru

\title{
GENRES OF SERMONS AND SPIRITUAL MESSAGES FROM EARLY MEDIEVAL EPOCH UP TO MODERN TIME
}

\begin{abstract}
The article presents main criteria of singling out sermons and spiritual messages, its common traits and differences. Besides, medieval sermons of Anglo-Saxon and New English period are considered, for which church-religious topic is basically typical unlike modern sources. Modern texts are inherent of spoken vocabulary, but Old English sermons are of Old English poetry nature.
\end{abstract}

Key words: sermons, messages, main criteria, common traits and differences

\section{ЖАНРЫ ПРОПОВЕДИ И ДУХОВНОГО ПОСЛАНИЯ ОТ РАННЕГО СРЕДНЕВЕКОВЬЯ ДО СОВРЕМЕННОСТИ}

Аннотация: В статье представлены главные критерии выделения проповеди и духовного послания, их общие черты и различия. Кроме того, рассматриваются средневековые проповеди англосаксонского и новоанглийского периода, для которых характерна, в основном, иерковно-религиозная тематика, в отличие от современного материала. Современным текстам свойственна разговорная лексика, в то время как у древнеанглийской проповеди- признаки древнеанглийской поэзии.

Ключевые слова: проповеди, духовные послания, основные критерии, общие черты и различия.

Гомилетика является одним из самых важных разделов теологии. Проповедь как устная форма выражения богословской тематики является разновидностью другого религиозного жанра-духовного послания как письменного документа Церкви. Как правило, содержательная сторона текста включает поздравление с христианскими праздниками; призывы-пожелания; религиозные наставления; восхваление деятельности церкви $[15$, с.9]. И.Ю. Ярмульская в своей работе распределяет все современные послания по пяти критериям: 1) по форме (устные и письменные); 2) по адресанту (единичный адресант и групповой); 3) по адресату (внутрицерковные и внецерковные); 4) по цели (информационные, дидактические и эпидейктические- о знаменательных событиях); 5)по тематике (праздничные и непраздничные) [17, с.1012]. В богословии понятие церковно-религиозного послания тесно связано с апостольскими и раннехристианскими посланиями. Общим для духовного послания и проповеди являются дидактизм, просветительство и эмоциональность. Некоторые ученые относят проповеди и церковно-религиозные послания к публицистическому стилю, но большинство включают их в особый церковно-религиозный стиль. «Особой эмоционально выражающей силой отличаются тексты, в которых видна личность проповедника, его собственный взгляд, психологическое состояние и эмоциональное настроение»... Подобная тональность называется многими исследователями индивидуально-авторской [3, с.21]. М.Б. Расторгуева отмечает, что тематика и содержание у проповедей шире и многообразнее, чем у посланий; есть различия и в образе автора, и характере адресата. В посланиях наиболее употребительна общекнижная лексика, а для проповедей типична церковно-религиозная наряду с разговорной лексикой. Для проповедей, в основном, характерен сакральный 
возвышенно-архаический стиль, в то время как в посланиях используется пласт газетно-публицистической лексики в отличие от лексики устной речи [13, с.5-6,16, 25]. По мнению И.А. Крыловой, в текстах проповеди взаимодействуют две тенденции: стремление к торжественности речи, с одной стороны, и попытки сделать речь живой и доступной для слушателей с другой. Первое проявляется в использовании высокой, устарелой и книжной лексики. Живой же речь становится при использовании разговорной лексики [5, с.18]. Американский ученый Джон Киллинджер (1996) различает в современной англоязычной гомилетике семь основных типов христианских проповедей: разъяснительный, развивающийся, дискурсивный или свободный, повествующий, классифицирующий, фасеточный или аспектный и экспериментальный [цит. по: 6, с.9]. По мнению В.А. Набиевой, проповедь является одной из функций церкви, это речь в церкви и от имени Церкви, которая имеет два лика: небесный«невеста Христова» и земной- «мать всех христиан». Отсюда и два различных направления в гомилетике, восходящие к древности: 1)риторическое-проповедь как вид красноречия, «слово разумения» (основоположник Блаженный Августин); 2) харизматическое - проповедничество как особый род человеческой деятельности, результат воздействия на человека «высших сил» (основоположник Григорий Великий -Двоеслов). Но второе направление было господствующим только в первые века существования христианства. В Руси, начиная с XVII в. утвердилось представление о проповеди как риторическом произведении, лишь известным образом приспособленном к церковному просветительству [10, с.6]. В своей работе М.В. Сибирева рассматривает проповедь не только как жанр церковного красноречия, но и как жанр духовной словесности в соответствии с традицией древнерусской литературы. Она выделяет проповедь в самостоятельный жанр древнерусской словесности [14, с.67]. А.А. Моллаева также относит проповедь к речевому жанру ораторского искусства. По ее мнению, к середине XVIII в. жанр проповеди получил расцвет и имел важное значение в истории русского литературного языка. «В процессе эволюции христианства отмечаются трансформация содержания религиозной проповеди, возрастание ее роли в социальной, культурной, нравственной сферах, проповеди получают скорее идеологическую, культурно-воспитательную направленность, чем теологическую. По мере включения церкви в решение политических, светских проблем, в сферу духовных исканий верующих, проповедь аппелирует к объектам, далеким от религиозной сферы. Наряду с проповедями исключительно религиозной тематики все чаще звучали проповеди просветительского характера...»[9, с.9,13]. Как подчеркивает в своей работе 3.Г.Шабанова, на начальном этапе становления проповедь была оформлена в виде беседы. Ее отличали обилие вопросно-ответных конструкций, явный диалог, но со временем проповедь оформляется как лекция - жанр ораторского искусства [16, с.9]. О.А. Прохватилова анализирует два основных направления в отечественной гомилетике. Риторическое направление восходит к грекоримской традиции толкования духовной проповеди и допускает использование в проповеди средств и приемов, которые накопила риторика. Антириторическое направление основывается на трактовке проповеди как воплощения Божественной энергии (харизмы), которая во время проповедования посылается священнику, а через него передается слушателям и не нуждается в особых средствах убеждения. Кроме гомилетики, проповедь является предметом изучения и общей риторики, в которой пастырское слово трактуется как вид духовного красноречия и ораторского искусства. Прохватилова предлагает многоаспектную классификацию современной православной проповеди по 7 критериям: 1) по времени, установленному для богослужения (в зависимости от годичного круга, недельного круга и суточного, т.е. проповедей вечерни, утрени и литургии); 2) по месту произнесения (храмовые и внехрамовые); 3) по адресату (монастырские, мирские и миссионерские); 4) по содержанию (эгзегетические -о 
Библии, панегирические-восхваление чего-либо важного, парэнтетические нейтральные наставления); 5) по цели (кериптические -об обращении иноверцев в христианство, катехизические о просвещении новообращенных, догматические и нравоучительные); 6) по способу изложения -аналитические и синтетические; 7) по форме -слово, поучение и беседа [12, с.32,34-35].Очень много исследований посвяшено изучению проповеди с языковой точки зрения. Например, О.А. Масурова согласна с разделением жанров церковно-богословского стиля на речевые (проповедь, исповедь, молитва) и богослужебные (акафист, епитимья, псалом) В современной лингвистической литературе анализируются психолингвистическая характеристика миссионерского текста (Саракаева, 2000), лексико-семантический аспект православной проповеди (Моллаева, 2003), особенности православного дискурса (Лапатухина, 2000), структурирование текста православной проповеди (Шабанова, 2006), построение христианской проповеди (Ивойлова, 2003), особенности стилистики православной проповеди (Расторгуева, 2000) и др. [цит. по: 8, с.3]. Можно провести отождествление проповеди и духовного послания в раннем средневековье (в частности, у англосаксов). Как такового термина «послание» у них не встречается. Можно говорить о жанре средневековой проповеди, которая одновременно и являлась посланием. Средневековые проповеди были по своей тематике, в основном, церковнорелигиозными, в отличие от современных. Очень значимая фигура в средневековой англосаксонской теологии-это монах Беда Достопочтенный (673 г.- 735 г.) из графства Ярроу, знаменитый историк и переводчик, единственный в Англии Доктор Церкви, канонизированный католической церковью. Беда писал проповеди не только о главных христианских праздниках (Рождественский пост, Великий пост или пасха), а также о разных важных событиях. Некоторые из его проповедей были собраны Павлом Диаконом и изданы, а св. Бонифаций как миссионер использовал их на континенте. Особенно известным проповедником является Эльфрик Эуншамский, монах-писатель и богослов. Его также отождествляют с Эльфриком Грамматистом и Эльфриком Кернским. С историко-литературной точки зрения, однако, наиболее интересны его ранние произведения - сборники проповедей и житий святых. Первый сборник проповедей Эльфрика возник в 990-991 гг., второй - в 994 г.; в каждом из них по 40 проповедей. Возникновение их связано, очевидно, с тем, что после реформы клиру было предписано каждое воскресенье обращаться с наставлениями к пастве; в целях наилучшего воздействия на слушателей они написаны на народном языке, а не на латыни, что придает им особый интерес. Требования общедоступности, которые ставил себе Эльфрик, распространяются и дальше, на самое содержание его проповедей. Он пишет ясно и просто, воздерживаясь от упоминания непонятных слушателям предметов, избегая, например, библейской экзотики и все время пользуясь запасом представлений из повседневного быта. Проповеди представляют значительный историко-культурный интерес, так как в них включены целые бытовые картинки. Второй сборник проповедей Эльфрика, а также сорок "житий", написанных им около 996/997 г., еще ближе к запросам времени и уровню его читателей, но в этих книгах сильнее, чем прежде, звучат призывы к покаянию; они написаны в период нового усиления датских вторжений. Рассказав, например, по библии о Маккавеях, Эльфрик, несомненно, имея в виду датчан, призывает соплеменников храбро сражаться с язычниками. В проповеди "Богомолец, работник и воин" он обсуждает, очевидно, злободневный тогда вопрос о непригодности монахов к военной службе, а проповедь "О ложных богах" целиком посвящает языческим верованиям скандинавских завоевателей Англии. В этих сборниках также силен повествовательный элемент; в проповеди вкрапливаются рассказы из жизни местных англосаксонских святыхнортумбрийца Дрихтхельма, мерсийца Иммы и др. "Жития" Эльфрика близки к художественной литературе и по той роли, какую они играли для читателей этой эпохи, 
являясь, в сущности, занимательными в сюжетном смысле повествованиями. В житие св. Свитуна он включает, например, даже воспоминания о своей собственной юности.. Из англосаксонских проповедников более позднего периода (X-XI вв.) рядом с Эльфриком должен быть упомянут Вульфстан, которого отождествляют с исторически засвидетельствованным между 1002-1023 гг. епископом Вустерским и архиепископом Йоркским. Он считался замечательным оратором, и перу его приписывали свыше пятидесяти проповедей. От Эльфрика Вульфстан отличается гораздо более изощренной стилистической техникой. Ему чужда простая повествовательная манера Эльфрика, и он вообще избегает повествований, даже касаясь библейских эпизодов. Вульфстан суровый моралист и беспощадный обличитель. Он обращается к современникам с гневом и горечью библейских пророков. Сильное впечатление оставляет относящаяся к 1014 г. “Проповедь Волка к англам” в то время, когда они особенно угнетаемы были датчанами. Бедствия времени пробудили в Вульфстане ораторский дар; он призывал к покаянию, громил распространенные в народе мирские забавы, предлагая, например, сжечь музыкальные инструменты. Смело обличал он также англосаксонскую знать. В тот период, когда Англия переставала уже жить самостоятельной государственной жизнью, он бесплодно старался сплотить национальные силы, остановить начавшееся общественное разложение, расшатывавшее нравственные устои. Этим объясняется продолжительность его влияния на литературные и даже юридические памятники последующей эпохи; проповеди Вульфстана использованы, например, в законах Данута. Следует особо остановиться на пяти известных эсхатологических проповедях Вульфстана. Он был убежден в близком конце света, говоря о постоянных грабежах викингов и ухудшении нравственности англосаксов, а также о том, что Антихрист уже рядом. Он призывал всех покаяться и не грешить перед концом света [2, с. 1-4]. По мнению Ю.Н. Карыпкиной, эсхатология есть суть «бытие» - «его уничтожение» -«возрождение» и представляет собой учение о Страшном Суде в конце всех времен. Эсхатологию принято делить на две большие части: одна часть - о небесах, рае и аде (это «большая» эсхатология), а другая («малая» эсхатология) - о Страшном Суде и судьбе Земли. Концептосфера «малой» эсхатологии в языке англосаксов представлена такими ключевыми концептами, как смерть, душа, суд, грех, ад и рай $[4$, с.3,5]. Большое внимание в проповедях уделяется различиям между язычеством и христианством. Например, язычники молились дубам и утесам. Для них дуб- это Космическое дерево (Мировое Древо), верхушкой соединенное с небом золотой цепью, по которой ангелы восходят в рай [цит. по: 18, с.146]. Основу вертикальной проекции составляет архетип Мирового Древа, которое связывает землю, где живут люди, с небом, а также символизирует середину мироздания [1, с.5]. Кроме того, сохранились сборники анонимных проповедей Х в. «Бликлинг». М.П. Омельницкий исследует две анонимные проповеди, в основе которых лежат агиографические источники. Проповедь о святом Неоте, жившем в конце IX в., представляет собой уникальный источник, т.к. ни Эльфрик, ни другие авторы позднего англосаксонского периода истории не оставили о святом никаких произведений на древнеанглийском языке. Латинская версия «Житие святого Неота» существовала. Вторая анонимная проповедь о святом Чаде, епископе и исповеднике. По мнению Омельницкого, появление в XII в. цикла проповедей об англосаксонских святых было вызвано желанием сохранить уходящую англосаксонскую традицию [11, с.12]. В работе Н.М. Кукушкиной рассматриваются различные проповеди в ранненовоанглийский период (конец XVв. и XVI-XVII вв.). По ее мнению, в ранненовоанглийский период складывается модель текстотипа проповеди, имеющая большое сходство с современным текстотипом и относится к публицистическому стилю. В отличие от древне- и среднеанглийского периодов расширяются рамки жанра: создаются проповеди, посвященные социально значимым событиям (похороны, открытие школ). Так, древнеанглийские проповеди 
обнаруживают черты древнеанглийской поэзии, традиции которой были утрачены в среднеанглийский период. Для современных текстов более характерна разговорная речь, в то время как ранние тексты не обладали этой особенностью. В ранненовоанглийский период в рамках жанра проповеди выделилось два направления: католическое (консервативное) и протестантское. Благодаря Реформации в XVI в. Британская церковь могла использовать родной язык вместо латыни для богослужебных целей и перевод Библии на английский язык. Например, профессор теологии Уиклифф в своей проповеди «О прелатах» призывал паству к устранению пороков высшей церковной и светской знати, а Хью Латимер, известный протестантский проповедник работу проповедника сравнивает с трудом пахаря в «Проповеди о пахарях» (1548 г.). Одним из основных убеждений Латимера была идея о доступности Библии простому народу. Ланселот Эндрюс (1555-1626) был известен сложностью своих проповедей, многие из которых он читал перед королем Джеймсом и они были адресованы для ученых богословов, а не для простого народа. Известный как поэт, современник У.Шекспира, Джон Донн также писал проповеди, в которых он уподобляет мир театру («Пасхальная проповедь», 1628 г.). Томас Адамс (1612-1653) разбивает свою известную проповедь «Распятие-Проповедь о страсти» на части (подобно разбору предложения по составу), каждая из которых является ответом на свой вопрос и подвергается трактовке. Влияние идей эпохи Просвещения, или Века Разума, находит свое отражение в произведениях и проповедях Джорджа Уайтфилда (1714-1770) -«Преимущества раннего благочестия» и «Необходимость и польза религиозного общества». Некоторые его проповеди были адресованы женской аудитории (например, «Христос как лучший муж», «Мудрые и глупые девы») [7, с.5, 912,14-15,17-18].

\section{References:}

1. Галкина И.А. Средства выражения пространственных отношений в древнеанглийском языке.-URL: http://www.dissercat.com/content/sredstvavyrazheniya-prost...Дата обращения: 12.10 .12 г.

2. История английской литературы.-URL:http://svr-lit.niv.ru/svr-lit/istoriya-anglijskojliteratury/prozaicheskaya-literatura-anglo-saksov.htm. Дата обращения: 21.02.14 г.

3. Ицкович Т.В. Православная проповедь как тип текста. Автореф. дис. канд. филол. наук. Екатеринбург, 2007. - 23 с.

4. Карыпкина Ю.Н. Языковое представление эсхатологических мотивов в англосаксонской прозе X-XI вв. (лингвоэтнический аспект). Автореф. дис. канд. филол. наук. Иркутск, 2002. -19с.

5. Крылова И.А. Современная православная проповедь в функциональностилистическом аспекте. Автореф. дис. канд. филол. наук. С.-Петербург, 2005.-19 с.

6. Крымская Е.В. Просодические средства реализации воздействующей функции в жанре проповеди (на основе американского варианта английского языка). Автореф. дис. канд. филол. наук. Волгоград, 2009.- 23 с.

7. Кукушкина Н.М. Эволюция жанра проповеди в новоанглийский период. Автореф. дис. канд. филол. наук. С.-Петербург, 2004.- 19с.

8. Масурова О.А. Структурно-семантическая характеристика русской православной проповеди конца XX - начала XXI вв. -URL: http://www.dissercat.com/content/structurno-semanticheskaya. Дата обращения: 19.07.11 г.

9. Моллаева А.А. Лексико-синтаксическое своеобразие православной проповеди XVIII в. Автореф. дис. канд. филол. наук. Махачкала, 2004.- 30 с. 
10. Набиева В.А. Прагматический аспект дискурса современной литургической проповеди. Автореф. дис. канд. филол. наук. М., 1996.- 21 с.

11. Омельницкий М.П. Агиографические модели позднего англосаксонского периода.-URL: http://www.dissercat.com/content/agiographicheskie-modeli-p...Дата обращения: 12.07.11 г.

12. Прохватилова О.А. Православная проповедь и молитва как феномен современной речи. Автореф. дис. д-ра филол. наук. М., 2000.- 46 с.

13. Расторгуева М.Б. Речевой жанр церковно-религиозной проповеди. Автореф. дис. канд. филол. наук. Воронеж, 2005.- 26 с.

14. Сибирева М.В. Проповедь митрополита Филарета (Дроздова) в русской литературе: проблемы жанра и стиля.-URL: http://www.dissercat.com/content/propovedmitropolita-filar...Дата обращения: 18.07.11 г.

15. Со Ын Ен . Речевой жанр современного церковно-религиозного послания. Автореф. дис. канд. филол. наук. М., 2000.- 15 с.

16. Шабанова 3.Г. Лингвистические средства воздействия православной проповеди (в историческом аспекте). Автореф. дис. канд. филол. наук. Махачкала, 2006. -20с.

17. Ярмульская И.Ю. Духовное послание в документоведческом и стилистическом освещении. Автореф. дис. канд. филол. наук. Волгоград. 2006.- 24 с.

18. Solomonik-Pankrashova T. Semantics of Old English feorh: from pagan to Christian tradition.- URL: http://www.phil.muni.cz/phonedata/wkaa/offprints\%20THEPES\%20. Дата обращения: 20.11.12 г. 